much less if their only motive has been the desire to get on in the world, powerful as that motive is, should be chosen for places of honor in public life, and made heroes of because of their demonstrated ability to yield to great temptations successfully, any more than the teaching of Christian tolerance requires that Magdalenes should be chosen to officer suffrage clubs and educational societies.

\title{
THE BUDGET AMENDMENT OF THE MARYLAND CONSTITUTION ${ }^{1}$
}

\author{
BY DR. WILLIAM H. ALLEN \\ New York City
}

W

HATEVER congress may do with respect to the proposed espionage bill, it has not yet passed a law declaring it to be lése majeste for students of budget-making to discuss frankly budget proposals from however eminent a source.

The fact that the Maryland budget law was devised by men who "labored for months without money compensation" and by other persons "who have had long experience in governmental matters relating to finance," is a reason why that law should be seriously studied. It is absolutely no reason why after studying it any citizen should either withhold question and criticism or confuse both by throwing futile bouquets at the distinguished participants.

The fact that the governors' conference, meeting and working as we know it did. in a hurry under pressure from no budget analysts except those who wanted this particular amendment, unanimously endorsed the Maryland plan, is again reason why the rest of us who are interested in state budget-making should do the studying which the governors' conference omitted.

Could anything be more absurd than for a group of budget analysts wishing to improve budget-making to spend time writing "expressions of appreciation of the many admirable features of the Maryland amendment and . . . self-sacrificing work done by those responsible for its initiation and completion," after once being convinced that this

${ }^{1}$ As was stated in the editorial note attached to Mr. Chase's review of the critical pamphlet issued by the institute for public service entitled "Serious Defects in Maryland's Budget Law," certain questions were formulated by Dr. Cleveland to develop certain aspects of the points at issue. These questions were in turn submitted to Dr. Allen, the director of the institute. In this article he answers fifteen of the twenty-eight questions submitted on the ground that adequate answers to the other questions which are of a technical nature would take more space than is availabie in the NATIONAL MUNICIPAL REVIEW, and further might tend to confuse the issues. The nature of the questions that Dr. Allen answers is intimated in his article, parts of which are also devoted to answering the review of Mr. Chase published in the May issue (page 395).-EDItor. 
amendment means a step in the wrong direction by state constitution makers!

Instead of analyzing our comment as we had analyzed the Maryland amendment, Mr. Chase asks readers of the National Municipal Review to believe that our analysis was prompted by a desire to sell services. On the contrary, these last two years we have spent, without cost to states and congress, several thousand dollars in answering questions, analyzing proposed laws, making budget comparisons, - all the time doing our best to interest budget makers and taxpayers in the proposition made October 17, 1916, in our Public Service No. 45: "It is not obtainable information but unescapable information which will improve state government."

To the institute for public service group budget-making is not a new, commercial or academic question. The institute for public service group, disparagingly contrasted with the Maryland law sponsors by Mr. Chase, consists of men long identified with budget propaganda and installation in the public's interest. We have been doing our best to keep this question of budget-making down to the ground within the comprehension of officers, editors and taxpayers.

In its pamphlet entitled Serious Defects of Maryland's Budget Law the institute for public service meant what it said. Instead of sneering at the Maryland production, as Harvey S. Chase wrote in the May number, the pamphlet took up earnestly, from conviction, straight-from-theshoulder what we consider serious defects of the budget law.

We know from firsthand experience the price any community pays for failing to see that it is budget intelligence and not so-called budget science that determines whether a community gets light or darkness out of budget reform.

To answer categorically the 28 questions sent to me by Dr. Cleveland through the editor would take more space than is available. Four typical issues have been selected to indicate why we use the term serious when speaking of defects of the Maryland budget law.

\section{WHAT BUDGET COMPARISON SHOULD BE MADE?}

Questions 1 to 3 ask if it is not enough to have budget requests compared with the two fiscal years preceding, since previous budget documents would contain the facts from which comparisons with earlier years might be made. . Our answer is No, because it is only unescapable information which really gets to the legislators.

\section{MAY OR MUST GOVERNORS EXPLAIN BUDGET RECOMMENDATIONS?}

Questions 10 and 11 relate to our comment upon Maryland's provision that accompanying each budget shall be a statement showing "(5) any explanation the governor may [sic!] desire [sic!] to make as to the important features of any budget and any suggestions [maybe desired, maybe not] as to the methods for reduction or increase of the state's revenue." 
What we said in addition to the bracketed items we repeat here:

Desires of governors are poor safeguards for taxpayers. What governors know is vastly more important than what they desire.

What governors ought to find out and publish is the proper subject of legislation and constitutional amendment. Suppose the governor does not desire to make explanations; suppose he lacks the facts with which to make the explanations as he will do under the Maryland amendment? Other states should make it mandatory upon the governor to give explanations not only as to features he personally considers important but as to every feature in the entire instrument which shows a departure from the preceding budget.

Ohio's governor in 1915-16 explained in detail all recommendations, increases and decreases, consolidations, etc., recommended. Wisconsin's legislature in 1915 provided that all increases and decreases should be separately set up and should be explained.

\section{BUDGET INCREASES BY MEANS OF SPECIAL BILLS}

Questions 19 to 23 relate to the Maryland provision that the legislature may not increase any budget items except for the general assembly and judiciary. We are asked if it will not suffice to make any increases in the form of special bills. To elaborate our answer would need a whole article. Instead we condense our original criticism:

Certainly any legislature ought to be permitted to increase the provisions made by any state for public schools; nor should it be necessary to amend the state constitution in order to increase the salary of a constitutional office

The Maryland law not only fails to give a hearing to those who know these facts about the insane but prevents even the introduction of a supplementary bill until after the executive budget bill has been voted. This will in most legislatures be the last week if not the last hour of the session

Practically, as well as legally, this Maryland law confuses and muzzles the legislative branch, administrative officers who know of needs not provided for by the governor, and the public

Conceding that it is important not to confuse the governor's program with anybody else's program and that it is desirable to fix squarely upon the executive's shoulders responsibility for his recommendations, it still remains possible to foster discussion and to use legislators for promoting public welfare

So long as the supplementary bill is known to everyone not to originate with the governor is there not every reason for having a supplementary bill with respect to the care of the insane before the legislature and considered by it at the same time that it considers the governor's proposals for the insane?

\section{ARE TAXPAYERS' HEARINGS NECESSARY?}

Questions 24 to 28 relate to Maryland's failure to provide for or mention taxpayers' hearings or compulsory hearings of governor and administrative officers.

We are asked if the provision is not enough that the governor or persons designated by him "shall have the right, and when requested by either 
house of the legislature it shall be their duty to appear and be heard with respect to any budget bill . . . and to answer inquiries relative thereto." We are also asked what has been the result of public hearings in New York city.

We and you are told that "the public hearings in New York city have had little or no effect on the determinations of the board of estimate." Even if that statement were true it would not prove to the institute for public service group that public hearings are a mistake. Perhaps it would only prove that New York had been inadequately or badly led and that eight years of reform had progressively disfranchised the public.

Whether or not taxpayers' hearings in New York city and New Jersey have been a failure, Maryland's omission of taxpayers' hearings emphasize a fundamental difference between those who are backing the Maryland law and others, like ourselves, who declare that it is seriously defective.

It was a disbelief in taxpayers' hearings (which includes what leads up to and follows them by way of citizen study and newspaper publicity) by the groups back and ahead of the Maryland law to which we referred in the statement quoted by Mr. Chase: "The institute for governmental research financed by the Rockefeller foundation and associates upon a platform that unequivocally disregards, where it does not unequivocally disrespect, public ability and right to understand and discuss budgetary questions."

Frankly, I am among those who believe that the right of the taxpayer to be shown legislative proposals and to be heard regarding them is among the bedrocks of democracy's fundamentals. Taxpayers have a right to stay away from taxpayers' hearings. They have a right to be foolish and unreasonable at hearings. They also have the right to come before city and state and national appropriators of public money, armed with constitutional and statutory rights to be informed and to be heard before their money is spent.

To argue, as Dr. F. A. Cleveland seems to, that because "almost no one except the few parties interested have attended," therefore "New Jersey's public hearings were fruitless," seems very much like arguing that because the public conducts itself in an orderly way all around our traffic police it is no longer necessary to have traffic police.

For the same reason that Governor Hughes when removing Borough President Ahearn said that "the majority, no matter how large, has no right to inflict upon the minority, no matter how small" an incompetent government, so believers in taxpayers' hearings answer those who consider them unnecessary and fruitless: "The majority, no matter how large, has no right to take from a minority of even one, the right to be told what budget alternatives are and to be heard regarding them before it is too late."

But what little bird told the institute for governmental research, the 
Rockefeller foundation and subsidiaries that taxpayers' hearings in New Jersey and New York have been a failure? Hon. Arthur N. Pierson, to whose leadership is due much of New Jersey's constructive legislation of last winter, said this morning by telephone:

On bills requiring budget plans for cities and counties our commission held hearings during 1916 in four or five cities. These were largely attended and spirited discussions were held. Hearings lasted until late in the afternoon. One taxpayers' hearing in Trenton began at ten o'clock in the morning and we were obliged to adjourn late at night before all the bills could be discussed. Great interest was manifested by crowded roomsful.

New Jersey has never yet tried bona fide public hearings on appropriation bills. We are just putting in a governor-made budget. A taxpayer is invited to the hearing. It does him good whether he comes or not. The fact that officers know a taxpayer may come does both the taxpayer and officer good no matter how many come. Budget measures will be vastly better analyzed wherever officers know that the public will have its day in court.

As for New York city, let us begin by telling what other people think of taxpayers" hearings before I answer the question as to "what are the concrete results of public hearings . . . that could not have been accomplished by petition, remonstrance and presentation through representatives."

The latest official answer is a bill just passed by New York's legislature proposed by a "Tammany" aldermanic president and unanimously supported by a "Reform Fusion" board of estimate. Does this bill sneer at public hearings or fail to mention them? Instead it not only requires a public hearing but the date for such hearing is set 20 days before the budget is adopted, and it specifically forbids the board of estimate and apportionment to put any matter into the budget bill which has not been submitted to the taxpayers' hearing.

Were even Mayor Mitchel to run for re-election this coming summer on a platform that promised to discontinue taxpayers' hearings or even whispered a doubt about their value, no one would know that he was running.

Readers of the National Municipal Review will undoubtedly concede that Henry Bruère is entitled to an opinion on the subject of budgetmaking. In his New City Government written after visits to ten commission-governed cities and several budget-makings in New York, he says:

After a lapse of a reasonable period opportunity should be given at a formal hearing for taxpayers and others to appear with recommendations regarding proposed allowances. Where the budget is extensive and wide differences are likely to exist between estimates submitted and the tentative conclusion . . . it will be found desirable to afford taxpayers an opportunity to be heard on the estimates themselves. 
After five years of taxpayers' hearings on New York city's budget the bureau of municipal research mentioned among the city's advances "taxpayers' organizations, social workers, ministers, get advance information as to budget estimates and are invited to prepare and attend public taxpayers' hearings enough in advance of the final budget to permit of analysis and discussion." Among signers of this statement was Dr. F. A. Cleveland.

Nor as late as 1913 had Dr. Cleveland acquired a doubting Thomas attitude toward taxpayers' hearings. His Municipal Administration and Accounting says:

The independent advice thus obtained [from official sources] does not put the board in the position to become intelligent inquisitors. Preliminary estimates and statements of departmental needs should be made public in order that the people, in the press and in citizen organizations, may discuss each of the issues presented. Heads of departments may be cited to appear and answer interrogatories. Citizen bodies may be heard in support of the enlarging or discontinuing different branches of the public service. . . . After full hearings as to relative needs, the board may with much intelligence fix the gross amounts. . . . Gross budget allowances being tentatively determined, the public can be taken into the confidence of the board by having these tentative schedules published, with a day appointed for a hearing in order that taxpayers may appear and oppose or support hearings. By some such proceeding the budget-making body may have the benefit of the expression of public opinion at every important step on subjects which would require increase or decrease in expenditures.

One up-to-date illustration of taxpayers' hearings in New York city will have to take the place of a hundred I should like to write.

A year ago the board of estimate of New York was insisting that its proposed agreement with the New York Central railroad for removing its tracks from Death avenue and its nuisance from Riverside park was clearly in the public's interest. Back of this position were forces of unlimited wealth and unfathomable social prestige. Yet that agreement is not only lost to-day but has been publicly rebuked by an almost unanimous legislature which passed two laws, one providing for a special investigation, and a second making it impossible for the present city government to execute this contract until it has been approved by the very public service commission that has unanimously condemned the pending contract as inimical to public welfare.

It is true that only a few people went to the hearings. It is also true that "only those who were particularly interested" went, but these few were given-after public protest-respectful hearing and the facts they presented were told to millions of readers and repeated to thousands of auditors in clubs and people's forums. The few included spokesmen for the citizens union, city club, west end association, woman's league for the protection of Riverside park, institute for public service, etc. William 
R. Willcox was not a horde but was a host because of his extensive definite knowledge of transit questions.

For failing to prescribe a procedure that would give a state-officials, legislators, public-unescapable information with respect to budget alternatives, and for failing to keep officials conscious every moment of their budget-making that they could not have secrets from their public, we charge the Maryland amendment with having serious defects. Does any member of the National Municipal League wish us to withdraw either the defects or the serious?

\title{
MUNICIPAL ADMINISTRATION AND LEGISLATION:
}

AN ANALYSIS OF MEASURES SUBMITTED TO POPULAR VOTE AT THE NOVEMBER ELECTION.

\author{
BY FREDERICK REX ${ }^{\mathrm{l}}$ \\ Chicago \\ Second Installment \\ PUBLIC IMPROVEMENTS
}

The voters of Los Angeles adopted an amendment to the charter enlarging the city's power to provide for or require the elevation or depression of railroad tracks, there being a legal question as to whether this power rested in the city or in the railroad commission. The voters of the same city also approved an amendment of the charter authorizing the city to perform street work or any other work carried on under special assessment by a system of direct employment instead of by contract. It is further provided in the amendment that the city may adopt its own method for the financing of or payment for the work when accomplished. The voters of San Francisco defeated an amendment to the city charter permitting the people of San Francisco to order the raising of a given sum by means of a special tax for a specific improvement in installments extending over more than ten years in order to avoid the need of voting bond issues for projects which cannot be paid out of the ordinary revenues. It was urged in opposition to the measure that the special tax could be levied by merely a majority vote, while bond issues require a two-thirds vote and that no limitation was placed upon the amount of special taxes to be levied in any one year, thus permitting the levying of taxes amounting to practical confiscation. Two amendments adopted in the same city grant power to provide by ordinance a procedure for changes of street grades and work, the payment of assessments in installments and limiting the amount of installment payments of assessments. The voters of Detroit ratified an amendment to the city charter reducing the rate of interest

${ }_{1}^{1}$ Municipal reference librarian. 